\title{
REDISTRIBUTION OF INTERNAL FORCES IN COMPOSITE CONCRETE GIRDERS MADE CONTINUOUS VS. TIME
}

\author{
$U D C 624.042 .2: 666.982=111$
}

\author{
Snežana Mašović, Saša Stošić, Nenad Pecić \\ University of Belgrade, Faculty of Civil Engineering, Serbia \\ snezanamasovic@gmail.com
}

\begin{abstract}
Research on the long-term behavior of composite concrete girders made continuous is presented in the paper. Concrete precast element is cracked under construction load. Creep and differential shrinkage of precast and in-situ cast part of the girder also induce stresses in a structure. The subject of this investigation is redistribution of section forces in course of time for concrete girders subjected to change of the structural system. The aim of investigation is to verify design models and analytical procedures by experimental research.
\end{abstract}

Key words: composite structures, concrete, construction phases, creep, shrinkage, experimental research, nonlinear analysis.

\section{INTRODUCTION}

Since late 1950's, concrete bridges of small span were often build of precast prestressed girders with cast in situ deck slab. Initially, these bridges were constructed as separate spans, with concrete section consisted of the precast element and the cast in situ slab. For longer bridges, this procedure leads to "series of the simply supported beams" bridges. Expansion joints between the spans induce a number of functional difficulties. The most significant are accelerated deterioration and drive discomfort.

Creating a continuous structure from precast elements was quite a challenge for engineers. Various techniques for establishing continuous action were developed. At the beginning, continuity was established using postensioning, since the precast girders were usually prestressed, [8]. Nowadays, continuity is usually provided using deck slab reinforcement and rods, bolts or dowels, which are embedded into precast girders of the adjacent spans and connected to resist negative live load moments [4].

Literature on 'continuous for live load' bridges, points to their popularity for bridges of small to medium spans. On the other hand, the same questions concerning design 
guidelines are still unsolved. Among them, prediction of the long term behavior, caused by creep and shrinkage of concrete, holds significant place.

Bending moments ('restraining moment') at continuity joints are the most crucial feature of 'continuous for live load' bridges. PCA provided detailed guidelines to calculate them, based on experimental research from early 1960's [12]. Since than, several, mainly analytical, studies have been done to provide an improved method to determine the restraining moment, [6], [7], [9], [11] - [16]. These analytical procedures are compliant with experimental observations on the test models of PCA tests [11]. PCA tests [11] became an unofficial benchmark tests for this type of structure.

All above-mentioned researches have been carried out on prestressed precast girders. In case of prestressed girders, no cracks are expected under the permanent load. Nonlinear effects caused by cracking of the concrete are avoided.

At the Faculty of Civil Engineering in Belgrade an experimental research on long term behavior of two-span continuous reinforced girders began in 2007. [10]. Two specimens were made of precast reinforced beams with cast in situ upper part and continuity joint at middle support (set A). Two cast in place continuous girders of same span and load are set for comparison of the results (set B). Long term load was designed to cause cracking of the precast girder before casting the upper part of the section and the continuity joint (set A), while control models (set B) remained uncracked.

DIANA Finite Element System [3] has been used for analytical models and prediction of measured results. Results of nonlinear FE-analyses were in concordance with measured values.

\section{EXPERIMENTAL INVESTIGATION}

Modeling of the concrete structures is a challenging task. Scale factor plays an important role, especially in case of creep and shrinkage tests. The scaled model has lager surface area to volume ratio. It will dry faster and, therefore, both shrinkage and creep are increased. Furthermore, shrinkage is more affected than creep by scale factor. The effect of differential shrinkage is significantly larger in scaled models than in real structures. Nevertheless, scaled models under controlled environmental and load conditions are convenient for testing numerical procedures.

\subsection{Test girders}

Since scale factor affects model behavior in long term tests, girders used in this experiment are not intended to scale real structure. Girders are of rectangle cross section, cast in one (set B) or two steps (set A). Continuity joint (set A) is cast in the second step, together with upper part of the girder.

Cross section of the girders A1 and A2 is shown in Fig. 1. The height of cross section of girders $\mathrm{B} 1$ and $\mathrm{B} 2$ is $25 \mathrm{~cm}$, same as the total height of $\mathrm{A} 1$ and $\mathrm{A} 2$. For concrete bridge structures, self weight of precast girders is a large part of total permanent load. For these models, self weight of the precast girder is relatively small to produce stress level that is corresponding to real structures. To produce similar stress level as in a real structure, additional permanent load is applied at two points of each span $(2,2 \mathrm{kN}$ at each point spaced $1,0 \mathrm{~m}$ ), Fig. 1. Total permanent load is designed so that cracks due to the bending moments appear in the precast part of girders A1 and A2. 
Two pairs of precast girders (set A) were set on columns with spans of $3.0 \mathrm{~m}$, with their adjacent end faces $10 \mathrm{~cm}$ apart at the middle support. Total length of a single precast beam was 3,12 $\mathrm{m}$ (phase I). Total length of specimens A1 and A2 after casting of joints and upper part of girders was 6,34 m (phase II) as it was for girders B1 and B2. Specimens B1 and B2 were also positioned on double supports (spacing $22 \mathrm{~cm}$ ) in the middle to achieve identical spans as for the set A. Size of the cross section was $12 \times 25 \mathrm{~cm}$. Reinforcement was identical for all girders except for the lack of continuity of bottom reinforcement at middle support in set A. Disposition of models and load arrangement for long-term observing is shown in Fig. 1.

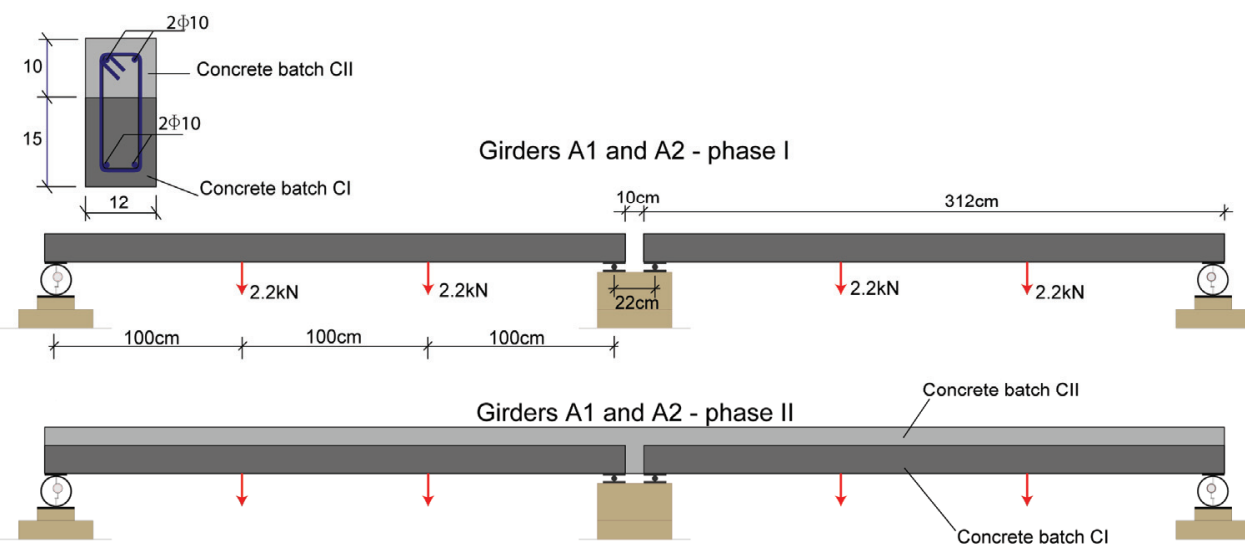

Girders B1 and B2

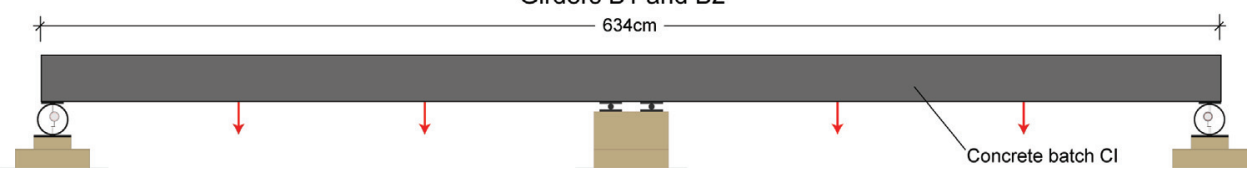

Fig. 1. Disposition of models A and B with long-term loading and model's cross section

Reinforcement in models of set A was designed using the common design practice. Self weight of the precast girder and weight of the upper part of section (together with additional $2,2 \mathrm{kN}$ load) were carried by girders section of the first phase $(12 \times 15 \mathrm{~cm})$ as simple beam, while live load is carried by composite section of continuous structure. It was assumed that span live load moment (phase II) is equal to the dead load moment of phase I. Continuity reinforcement is provided in the same amount as span reinforcement. It roughly corresponds to the negative reinforcement of continuous beam carrying live load similar to applied dead load.

Reinforcement in models of set B is identical as for set A. Reinforcement layout is shown in cross section in Fig. 1. 


\subsection{Test equipment}

Models were stored in laboratory under constant temperature $19 \pm 1{ }^{\circ} \mathrm{C}$ and relative humidity $78 \pm 2 \%$. Creep and shrinkage were measured by strain gauges on specimens also stored in the laboratory. In Fig. 2 set B models are presented.

Mechanical instruments were used for measuring of long-term strains, deflections and supporting reactions. Mechanical dynamometers were provided at end supports for measuring of reactions. Sensitivity of the mechanical dynamometer was less than $10 \mathrm{~N}$.

Attached strain gauges with a base length of $250 \mathrm{~mm}$ were used for measuring concrete strains. Concrete strains were measured in midspan sections at four levels (fibers) on both sides of section. The strain gauges attached through holes left in concrete cover were used for measuring reinforcement strains. The strain of bottom reinforcement was measured at midspan. The strain of top reinforcement was measured in the sections at the middle supports (continuity reinforcement for set A girders).

For measuring long term deflection mechanical deflection gauges with precision 0,01 $\mathrm{mm}$ were placed at the midspan of each girder. Control geodetic measuring of the midspan deflection was also taken during experiment.

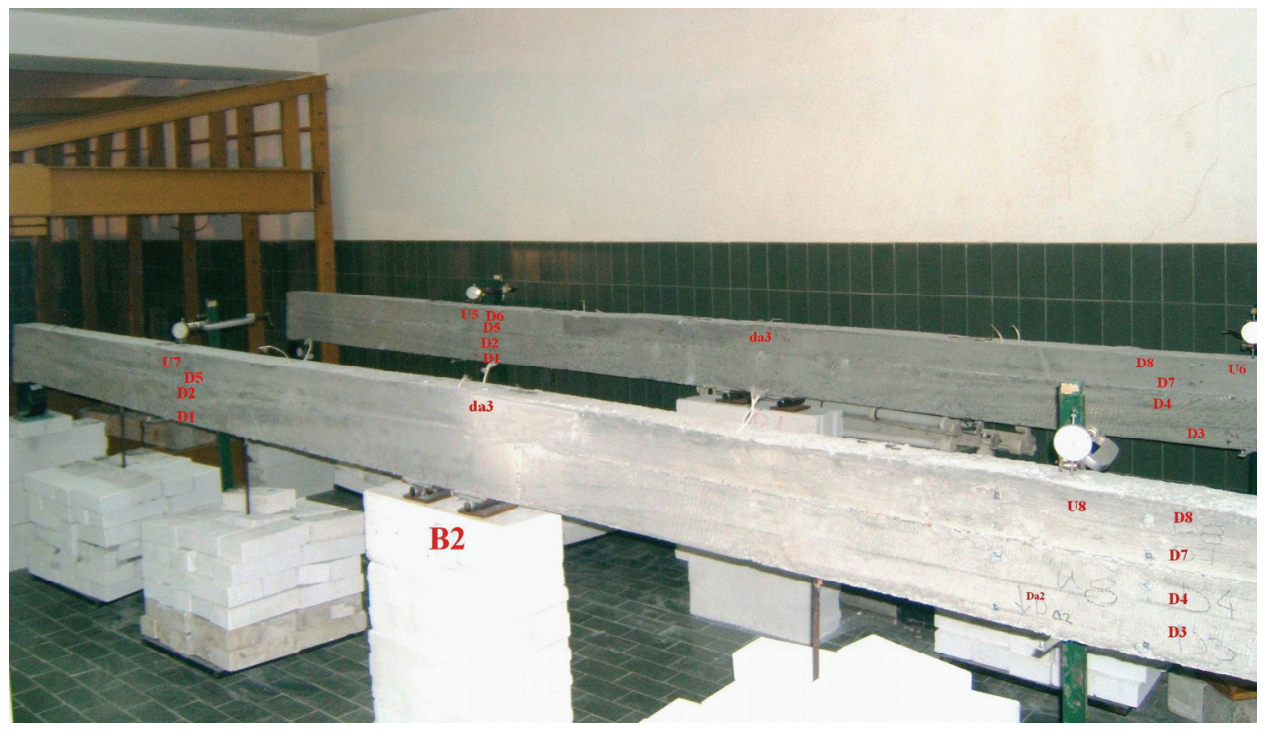

Fig. 2. Girders B1 and B2 with measurement points

\subsection{Testing schedule}

Girders were cast on November 12th 2007 and wet cured for 7 days. At the age of 28 days models were placed on the supports. Immediately after positioning models additional permanent loads of $2.2 \mathrm{kN}$ were hung from the girders at two points of each span, as it is shown on Fig. 1. These additional loads caused cracking of spans of set A girders and were followed with consequent deflections. At the same time, set B girders had no cracks under the load and showed significantly smaller deflections. After 14 days, when the pre- 
cast girders aged 42 days, upper parts of the set A girders $(12 \times 10 \mathrm{~cm})$, together with continuity joints, were cast. Instantaneous changes of deflection were measured by the geodetic devices. Readings were taken every two days for the first two weeks, than once a week during the next month, and once a month after.

\section{TEST RESULTS}

\subsection{Concrete properties}

Two concrete batches were used in the experiment. Concrete batch CI was used for precast girders of set A (phase I) and entire girders of set B. Batch CII was used for casting of upper part of set A girders and continuity joints (phase II).

Compressive strength was measured on cube specimens. Strength of the batch CI was $36,6 \mathrm{MPa}$ at the age of 28 days. Concrete batch CII 28 days compressive strength was $28,3 \mathrm{MPa}$. Prism specimens $12 \times 12 \times 36 \mathrm{~cm}$ have been used for measuring the flexural tensile strength at the age of 28 day for both batches. Flexural tensile strength were 4,5 $\mathrm{MPa}$ for CI and 3,1 MPa CII. Secant modulus of elasticity was determined on $15 \times 30 \mathrm{~cm}$ cylinders and showed values of 29,5 GPa and 22,7 GPa (CI and CII).

Development of shrinkage in course of time was measured on 3 prisms $(12 \times 12 \times 36 \mathrm{~cm})$ for each of two concrete batches. Specimens were stored in the laboratory with the girders, to ensure the same environmental conditions. Fig. 3 presents measured shrinkage strains $\varepsilon_{\mathrm{s}}(t)$ for both batches, together with ACI209 [1] and MC90 [2] prediction for the same conditions.

Creep strains were measured simultaneously with shrinkage to determine creep coefficient. Measured (total) strains $\varepsilon(t)$ were transformed into the experimentally determined creep coefficient $\varphi\left(t, t_{0}\right)$ using Eq. 1:

$$
\varphi\left(t, t_{0}\right)=\frac{\varepsilon(t)-\varepsilon\left(t_{0}\right)-\left(\varepsilon_{s}(t)-\varepsilon_{s}\left(t_{0}\right)\right)}{\varepsilon\left(t_{0}\right)}
$$

where $\varepsilon\left(t_{0}\right)$ is initial elastic strain.

This definition of creep coefficient is used in American practice. Creep coefficient in European practice (MC90 and EC2) is connected with the elastic deformation corresponding to the age of 28 days. Creep coefficients are related by Eq. 2 .

$$
\varphi^{A C I}\left(t, t_{0}\right)=\frac{E\left(t_{0}\right)}{E_{28}} \varphi^{M C 90}\left(t, t_{0}\right)
$$

where $\mathrm{E}\left(t_{0}\right)$ and $\mathrm{E}_{28}$ are secant moduli of concrete at the age $t_{0}$ and 28 days.

For measuring creep coefficient three prisms $(12 \times 12 \times 36 \mathrm{~cm})$ of concrete batch CI were subjected to sustained axial force at age of 28 day. For concrete batch CII, three prisms were loaded at the age of 15 days. Average values of creep coefficients (from three samples) for concrete CI and CII, together with MC90 and ACI209 prediction are shown in Fig. 4.

From Fig. 3, shrinkage strains of concrete CI are similar to MC90 shrinkage proposal, while concrete CII is closer to ACI 209 proposal. ACI 209 generally overestimates the value of shrinkage strains, especially for the batch CI. 


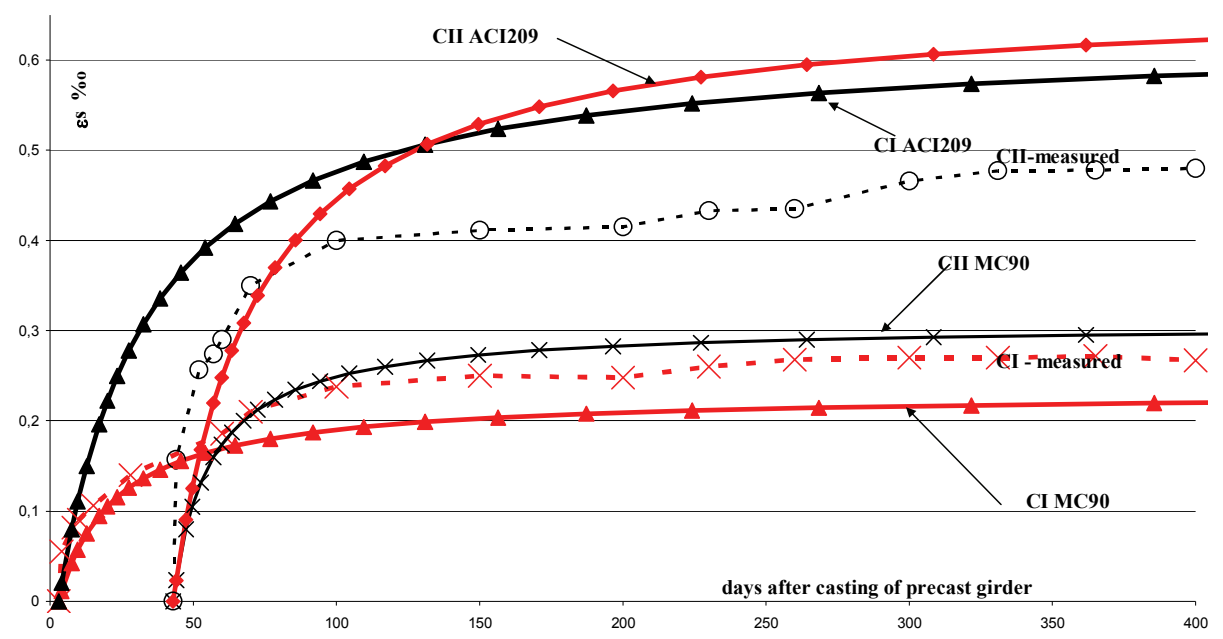

Fig. 3. Measured shrinkage strains in comparison with MC 90 and ACI 209 prediction for same conditions

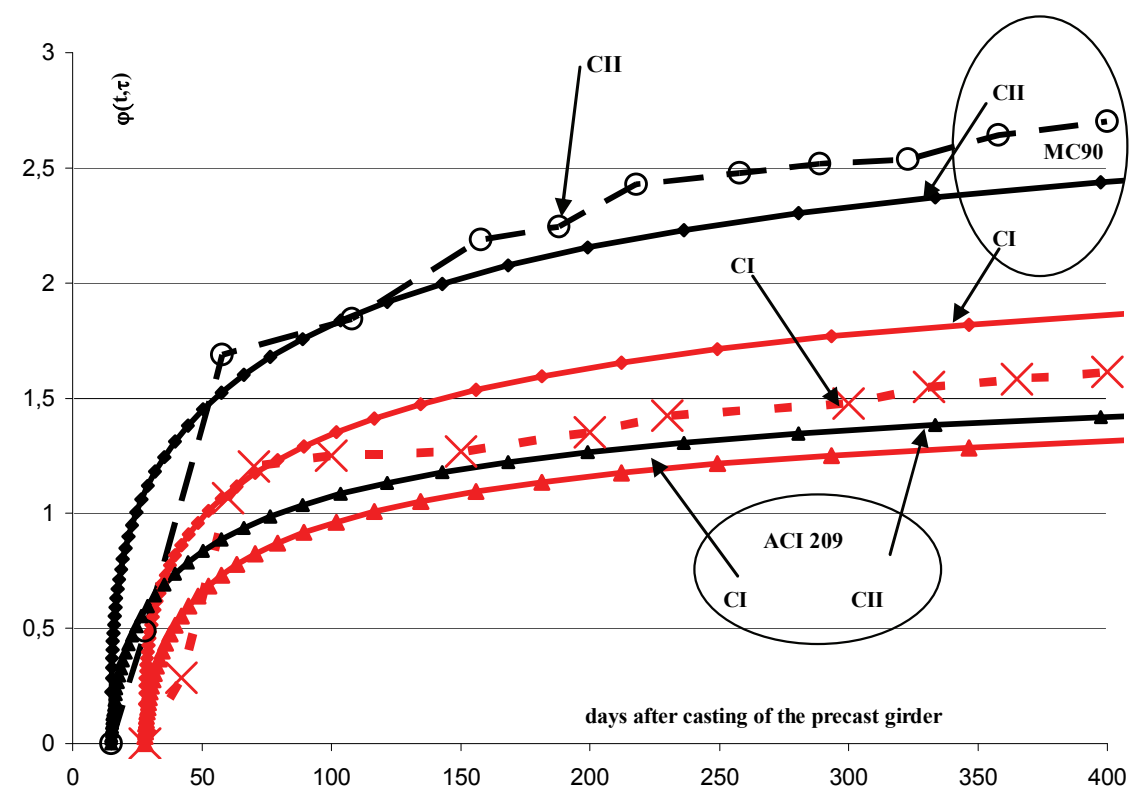

Fig. 4. Measured creep coefficient in comparison with MC 90 and ACI 209 prediction for same conditions 
From Fig. 4 it is apparent that creep properties of used concrete batches are better described with MC90 proposal. In both cases ACI 209 underestimates the value of creep coefficient.

\subsection{Long term measuring on the girders}

Long term measuring started after the girders were placed on the supports, at the age of 28 days.

Initial deflections of the set A girders were large in comparison with the set B girders. Set A girders were simple span at the time of loading, while set B were continuous. Besides, set B had no cracks under the load. In the following two weeks after loading (phase I of set A) there is a significant increase of the deflection for both sets. Instantaneous deflection increase of set $\mathrm{A}$ appeared at $42^{\text {nd }}$ day due to the load from casting upper part of the girders (models were not shored while casting). Deflection increase of set A significantly slowed down after establishing the continuity, Fig. 6, while set B remained gradual development of deflection, Fig. 7.

End support reactions of the A girders are changing continuously after continuity is established and indicated development of negative restraint moment at the middle support. Support reactions of the set B control girders also changed in course of time. Observed small changes were consequence of settling of the end supports due to deformation of the mechanical dynamometers only, since B girders were reinforced symmetrically and without cracks. Analytical study presented in the paper included deformation of the supports.

\section{NONLINEAR ANALYSES AND COMPARISON WITH TEST RESUlTS}

\subsection{FE model}

Experimental investigation of all test girders was simulated using the DIANA Finite Element System [3]. Due to symmetry of the models, only half of the girders were modeled.

Class II beam elements [3] can be numerically integrated over their cross section and along their axis. Therefore these elements may be used in geometrical and physical nonlinear analysis. They are based on the Bernoulli theory.

DIANA supports the feature of composed beams. As a consequence of construction technique, set A girders are composed of two parts made of different concrete. Certain elements of the model are inactivate or active in various analysis phases. Reinforcements are embedded in so-called mother elements. Perfect bond between the reinforcement and the surrounding material is assumed.

Finite element mesh consisted of 46 composed elements along the girder axes. There were 44 elements representing precast girder and 2 elements representing continuity joint. In Fig. 5 DIANA FE model is presented (half of the continuous girder). Precast girder elements are presented as red elements, while cast in place and joint are presented with yellow elements.

Mechanical dynamometer was modeled as a spring element with the experimentally measured stiffness of the device. 


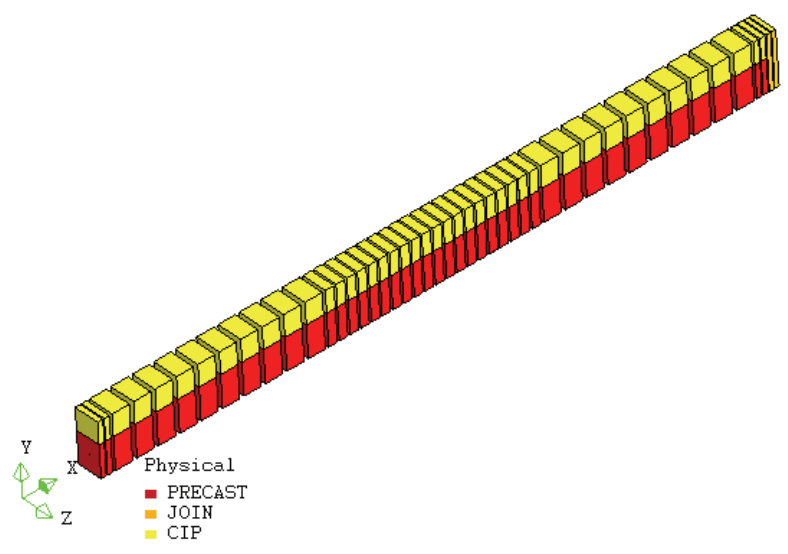

Fig. 5. DIANA FE model mesh

\subsection{Modeling of material properties}

Various material models for concrete are available in DIANA's system.

\subsubsection{Cracking}

Brittle cracking model was adopted in analysis. Constant stress cut-off with measured concrete tensile strength was applied for both concrete batches.

\subsubsection{Viscoelasticity}

Viscoelasticity is a type of material behavior with memory, so that the strain history affects the current stresses. Based on the principle of superposition, the creep function $(J(t, \tau))$ Eq. (3), is used to calculate the strain as function of the stress history, Eq. (4).

$$
\begin{gathered}
J(t, \tau)=\frac{\varepsilon(t)-\left(\varepsilon_{s}(t)-\varepsilon_{s}(\tau)\right)}{\sigma(\tau)}=\frac{\varepsilon(t)-\left(\varepsilon_{s}(t)-\varepsilon_{s}(\tau)\right)}{\varepsilon(\tau) E(\tau)}=\frac{1+\varphi(t, \tau)}{E(\tau)} \\
\varepsilon_{c}(t)=\int_{t_{0}}^{t} J(t, \tau) d \sigma(\tau)
\end{gathered}
$$

Volterra integral Eq. (4) can be solved in the closed form only in special cases and numerical procedures have to be adopted. Common numerical procedure consists in stepby-step solution of integral type creep law expressed by Eq. (4). Such procedure demands storage of complete stress history. Step-by-step procedure may be presented in a recurrent form if the creep function is adopted as a Dirichlet series Eq. (5). Physically, the Dirichlet series can be interpreted as a Kelvin-chain model or a Maxwell-chain model.

$$
J(t, \tau)=\sum_{i=1}^{n} \frac{1}{E_{i}(\tau)}\left(1-e^{-E_{i} \frac{t-\tau}{\eta_{i}}}\right)
$$

Creep behavior of concrete modeled by Eq. (3) is numerically adapted for solution protocol using selected Chain model. This concept is applied in DIANA. 


\subsection{Solution strategy}

DIANA Phased Structural Analyses was performed for solving nonlinear model of set A girders. Analysis includes two phases. In the first phase active parts were precast girders with bottom reinforcement as simple span beams. Start step of the second phase applies stresses from the first phase as initial conditions. In the second phase upper part of the girder with continuity joint and top reinforcement became active. Rotation was restrained at the continuity joint.

Nonlinear analyses were performed in each phase. Structure was already discretized into finite elements. A time discretization was performed as well (time steps) to enable numerical solution of viscous behavior. Load was also applied in steps for tracing cracks. Since the equations are not linear, an incremental-iterative solution algorithm was used to achieve equilibrium of external loads and internal forces at the end of each time step. Set $\mathrm{B}$ required nonlinear analysis without phases.

\subsection{Comparisons of results}

Various material models for concrete were used in numerical analysis: incorporated material models (MC90 and ACI209), Eurocode 2 and concrete with measured properties.

Comparisons of measured and calculated values of midspan deflection lend particular significance to the material properties prediction. In Fig. 6 (phase I) and Fig. 7 (phase II) measured and calculated values of the midspan deflection for set A are presented. Measured value is average of four results -2 (spans) $\times 2$ (girders).

When code predictions for creep and shrinkage are used, calculated deflections were larger than measured. MC90 performed closer values then Eurocode 2 or ACI 209. The best compliance was achieved using measured concrete properties. Calculated deflections of phase I with measured properties were very close to the observed values, Fig. 6.

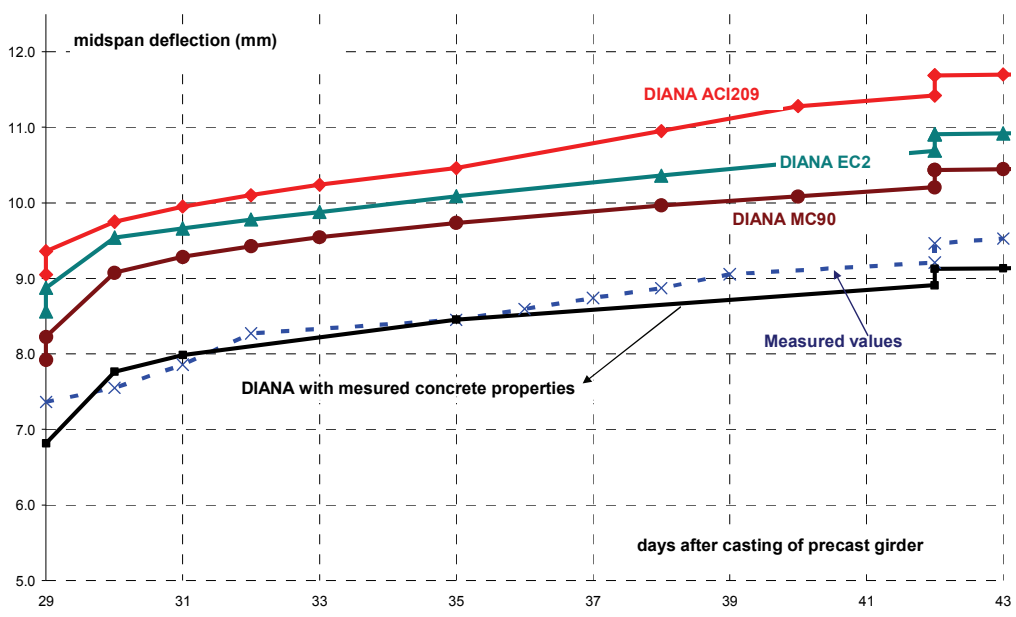

Fig. 6. Measured and calculated midspan deflection of A girders - phase I 
Calculated deflections for phase II were not so close to the measured values as for phase I, Fig 7, but the trend is similar for all material models. Redistribution of internal forces was the most probable cause. Three months after continuity had been established, increase of the deflection was negligible, Fig 7.

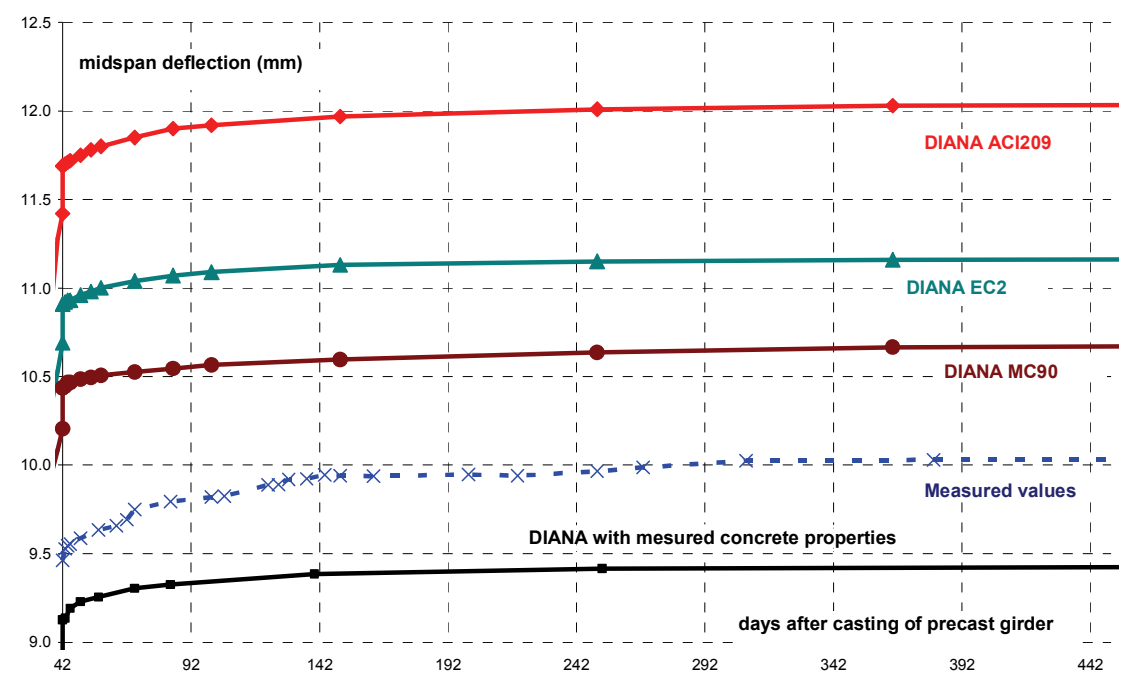

Fig. 7. Measured and calculated deflection of A girders - phase II

Deflection of B girders is presented in Fig. 8. Measured values are close to these obtained from nonlinear analysis, indicating good prediction of MC90 for material model.

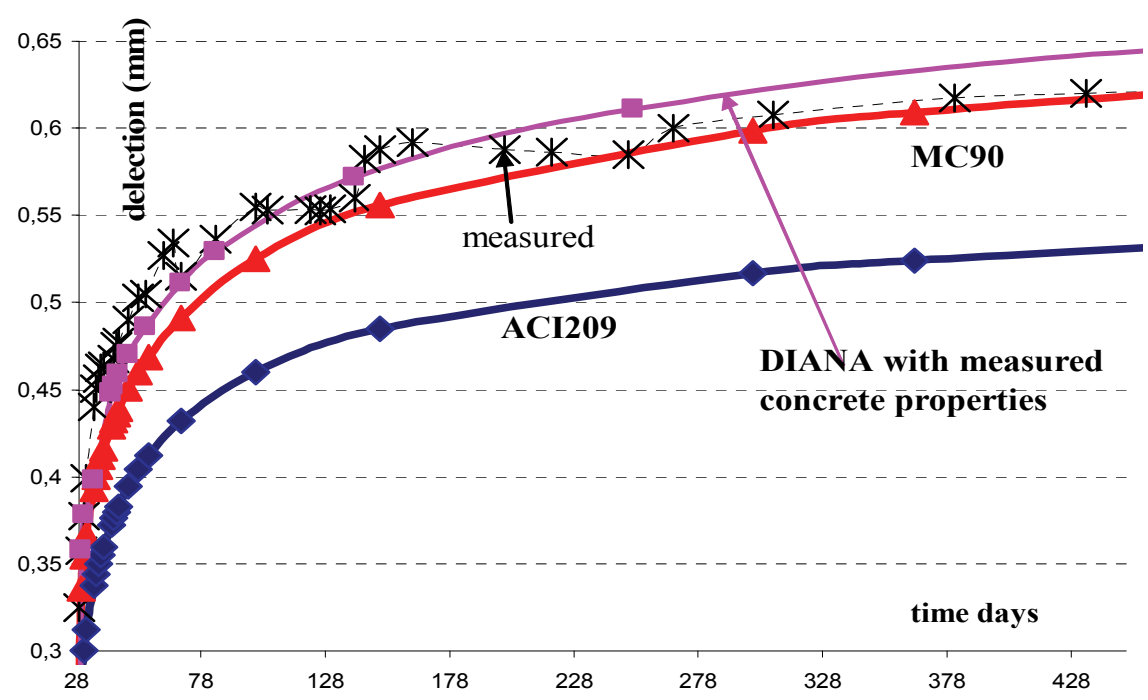

Fig. 8. Measured and calculated deflection of B girders 
Changes of the end support reaction indicated development of the negative restraint (continuity) moment which prevented further deflection increment.

Ratio between the restraint continuity moments $\mathbf{M}_{\mathbf{r}}$ (calculated from nonlinear analysis and from measured support forces) and the linear elastic moment of continuous beam $\mathbf{M}_{\mathbf{e}}$ is shown in Fig. 9. Linear value was obtained for continuous girder with elastic end supports corresponding to mechanical dynamometers.

Due to predominant differential shrinkage in the initial period, restraint moment developed rapidly in approximately first two months after beginning of the phase II. After that period, creep relaxed the effects of shrinkage diminishing negative restraint moment to its final value. Same tendency was observed in Mattock's tests [11].

"Measured" values of restraint moment (calculated from the reactions) reached about $50 \%$ of the values obtained by linear elastic analysis of continuous girder. Final value is approximately $35 \%$ of the elastic moment of continuous girder. This value is far below the elastic solution. It may be estimated that initial cracks of precast girder made the system more flexible to imposed deformations. This led to smaller restraint moments. Analytical values confirmed similar behavior.

Various material models for the viscous concrete properties result to quite different outcomes for the same analytical procedure. Best compliance with "measured" values of restraint moment were achieved for concrete model with measured properties presented in Fig. 3 and Fig. 4.

Among calculated values, it is apparent that Maxwell chain model gives better prediction than Kelvin chain model for a given material properties.

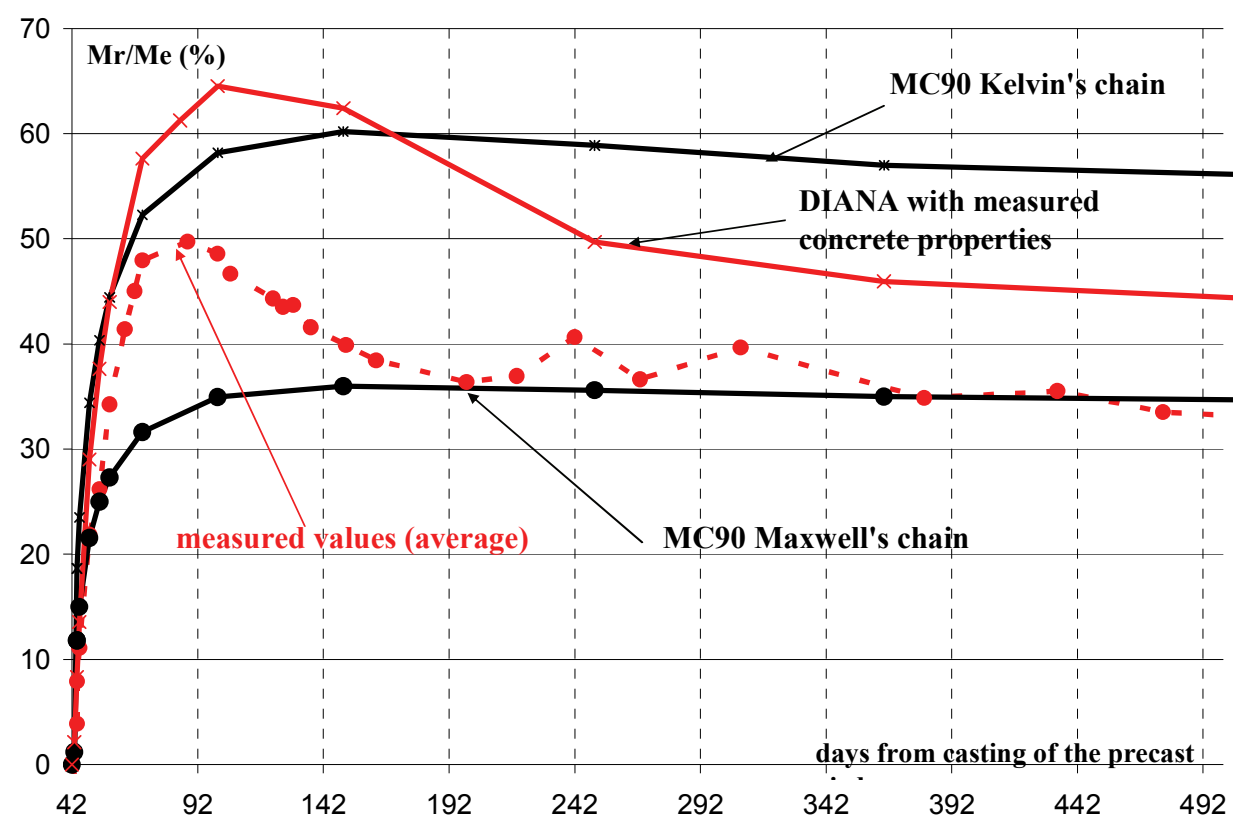

Fig. 9. Ratio of "measured" and calculated restraint moments to elastic value for A girders 


\section{CONCLUSION}

Experimental results obtained from long term tests of two sets of continues girders have been presented and compared with the results of nonlinear FE analyses performed with DIANA Finite Element System.

Based on the results of this study, conclusions are as follows:

- Restrained moment develops in continuity joint after the continuity is established due to creep and shrinkage of concrete. The value of this moment depends on many parameters. In specified case of reinforced cracked precast girders, the value reaches $30-70 \%$ of elastic moment for continuous girder.

- Deflections of the set A girders, that were constructed in phases, were significantly lager than simultaneous deflections of the continuous B girders of the same geometry and load as set A at final stage.

- Establishing of the continuity at mid support reduce the increase of span deflections due to creep and shrinkage.

- Previous experimental investigations have been performed on uncracked precast girders (prestressed precast girders). Comparisons of the results of presented experiment with previous experimental investigations show that cracks in the precast girder reduce restraint moment in the continuity joint. The same was confirmed with analytical model of DIANA Software.

- Material models that are used in analyses are of the most importance for prediction of the long term behavior. In reality, concrete can show different viscous behavior then described in commonly used code proposals. In design phase material properties of concrete are not fully available. Use of the various material models in design can provide upper and lower limits for structural response.

\section{REFERENCES}

1. ACI 209R-92, (Reapproved 1997), ACI Committee 209: 'Prediction of Creep, Shrinkage and Temperature Effects in Concrete Structures": American Concrete Institute

2. CEB-FIP Model Code 1990; Tomas Telford, 1993

3. DIANA Users Manuel - release 9-2 (2007), TNO DIANA, Delft, The Netherlands

4. Dotreppe, J.-C., Coonce, S., Kaiser, F.(2006)' The Use of Precast Prestressed Concrete Beams as Continuous Structural Elements in Bridges" Proceedings of the 2nd FIP International Congress(CDROM), FIB, Naples Italy, ID 6-29

5. EN 1992-1-1, Eurocode 2: Design of concrete structures - Part 1.1: General Rules and Rules for buildings,CEN, December 2004.

6. Halvonik, J. Borzovič, V., Fillo, L.(2006):" An Experimental Investigation of Composite Continuous Girders"; Proceedings of the 2th International Congress FIP, (CD-ROM), FIB, Naples Italy, ID 5-3

7. Hyo-Gyoung Kwak, Young-Jae Seo (2000): Long-term behavior of composite girder bridges, Computers\&Structurese Vol.74.,pp 583-599, Elsevier Science Ltd.

8. Kaar P.H., Kriz B., Hognestad E.(1960) Precast-prestressed concrete bridges: 1. Pilot tests of continuous girders. Journal of the PCA Research and Development Laboratories, 2 (2): 21-37.

9. Ma Z., Huo X., Tadros M.K., Baishya M. (1998) : Restraint Moments in Precast/Prestressed Concrete Continuous Bridges, PCI Journal Precast / Prestressed Concrete Institute, Vol. 43, No. 6, pp 40-56

10. Mašović S.(2008): "Redistribution of internal forces in composite concrete girders made continuous vs. time;" Ph.D. thesis, University of Belgrade, Faculty of Civil Engineering, Belgrade, Serbia (in Serbian)

11. Mattock, A. H. (1961). "Precast-Prestress Concrete Bridges: 5. Creep and Shrinkage Studies. Journal of the PCA Research and Development Laboratories, 3(2).pp 32-65 
12. McDonagh M.D., Hinkley K.B.(2003): Resolving Restraint Moments and Designing for Continuity in Precast Prestressed Concrete Girder Bridges; PCI Journal Precast / Prestressed Concrete Institute, Vol. 48, No. 4, pp 2-17

13. Mirmiran, A., Kulkarni, S., Castrodale, R., Miller, R., and Hastak, M., (2001) "Nonlinear Continuity Analysis of Precast, Prestressed Concrete Girders with Cast-in-Place Decks and Diaphragms", PCI Journal Precast / Prestressed Concrete Institute, Vol. 46, No. 5., pp 60-80

14. Miller,R.A., Castrodale,R., Mirmiran, A, and Hastak, M., (2004) 'NCHRP REPORT 519:Connection of Simple-Span Precast Concrete Girders for Continuity"; Transportation Research Board; Washington D.C.

15. Oesterle, R.G., Glikin, J.D., and Larson, S.C. (1989), "NCHRP Report 322: Design of Precast Prestressed Bridge Girders Made Continuous", Transportation Research Board, Washington, DC

16. Peterman R.J., J.A. Ramirez (1998): Restraint Moment In Bridges With Full-Span Prestress Concrete Form Panels, , PCI Journal Precast / Prestressed Concrete Institute , Vol. 43, No. 1, pp 54-64.

\section{PRERASPODELA UTICAJA KOD NAKNADNO KONTINUIRANIH SPREGNUTIH ARMIRANOBETONSKIH NOSAČA TOKOM VREMENA}

\section{Snežana Mašović, Saša Stošić, Nenad Pecić}

U radu je prikazano istraživanje ponašanja naknadno kontinuiranih betonskih konstrukcija, sa naglaskom na deformacije betona zavisne od vremena. Promena statičkog sistema tokom izvođenja, dovodi i do preraspodele statičkih uticaja u sistemu, tako da konačno stanje nije prost zbir faza kroz koje konstrukcija prolazi. Pored skupljanja i tečenja betona pod stalnim opterećenjem, pojava prslina utiče na razvoj napona i defomacija kroz vreme. Osim eksperimentalnog istraživanja, $u$ radu je prikazana i numerička analiza primenom programskog paketa DIANA za nelinearnu alanizu konstrukcija. Cilj prikazanog istraživanja je identifikacija najznačajnijih parametara za ponašanje konstrukcije tokom vremena i verifikacija proračunskih modela.

Key words: transformacija statičkog sistema, beton, sprezanje, tečenje, skupljanje, nelinearna analiza. 